Article

\title{
Greenway Implementation Influence on Agricultural Heritage Sites (AHS): The Case of Liantang Village of Zengcheng District, Guangzhou City, China
}

\author{
Fei Zhao ${ }^{1,2} \mathbb{D}^{\mathbb{D}}$, Rui Nie ${ }^{1}$ and Jia'en Zhang ${ }^{2, *}$ \\ 1 Institute of Chinese Agricultural Heritage, South China Agricultural University, Guangzhou 510642, \\ Guangdong, China; zhaofei@scau.edu.cn (F.Z.); nierui@stu.scau.edu.cn (R.N.) \\ 2 Institute of Tropical and Subtropical Ecology, South China Agricultural University, Guangzhou 510642, \\ Guangdong, China \\ * Correspondence: jeanzh@scau.edu.cn; Tel.: +86-20-85285505; Fax: +86-20-85285505
}

Received: 28 December 2017; Accepted: 2 February 2018; Published: 7 February 2018

\begin{abstract}
As environment-friendly recreational facilities, greenways can bring ecological, social, and economic benefits to the residents of agricultural heritage sites (AHS). Zengcheng District of Guangzhou City first implemented the recreational greenway in China in 2008. Liantang Village is the tourist center of the Liantang Spring segment of Zeng River Greenway system. This village has always been an important planting region of black olive and lychee from ancient times, with more than 1800 large old trees until today. Taking Liantang as a case, participant observations, in-depth interviews, and questionnaires $(n=140)$ are performed to collect relevant data. This study explores the economic and sociocultural influences of greenway implementation on AHS. Findings reveal that greenway tourism and agricultural heritage conservation form a mutually beneficial relationship. The greenway implementation successfully prompts the emergence and rapid development of tourism which significantly improves the economy of the heritage area and effectively increases the income of the villagers in AHS. The sources of their income mainly include agritainment businesses, agricultural product sales, tourist-related business wages, land leases, and house rentals. Most villagers greatly improve their quality of life because of the continuous infrastructure improvements. However, the daily lives and production orders of villagers are disturbed to some extent. The villagers have a highly sober cognition of the value of old trees, and their protection consciousness is enhanced. The difference in the source of economic income affects the judgment of the villagers, and three groups of villagers exhibit some cognitive differences with the influence of tourism. Results indicate that multi-dimensional values of agricultural heritage can be achieved, and a mutually beneficial relationship will then be formed between tourism and agricultural heritage conservation as soon as the correct eco-tourism is developed in AHS.
\end{abstract}

Keywords: greenway; agricultural heritage site (AHS); greenway tourism; tourism effect; old tree; black olive; lychee; dynamic conservation; southern China

\section{Introduction}

Greenways are linear open spaces along natural or artificial corridors, such as riverfronts, streams, ridgelines, abandoned railroad right-of-ways, canals, or scenic roads [1]. Recreational greenways that originated in the USA have rapidly become an international movement since the mid-1990s. The first scholar who systematically expounded on the concept of greenway is Charles Little, a famous American environmental writer. In 1990, he published his seminal book, Greenways for America, the metaphor that has galvanized the greenway movement in America [2]. According to Little, a greenway is a natural, protected linear corridor that improves environmental quality and provides 
outdoor recreation [3]. The implementation of the modern greenway increasingly attached importance to matching leisure functions. Greenways include trails for active recreational use, such as walking, running, bicycling, and skating. Kongjian Yu, a famous landscape architect, summarized the evolution of greenway planning and implementation in China. Based on his paper, although the concept of the greenway is an adaptation from the Western world, the Chinese have a history of more than 2000 years of greenway planning and implementation. The functions of greenways are mainly protective and productive, with minimal concern for human uses, such as recreational uses of cycling and hiking [4]. Zengcheng District of Guangzhou City, Guangdong Province, initially planned and implemented large scale recreational greenways in 2008. Nowadays recreational greenways have spread rapidly in China because of the popularity of its concept and its successful practice in Guangdong.

\subsection{Literature Review}

The multiple benefits of greenways have attracted increased attention since 1980s. Little emphasized the positive influence of greenway implantation by saying, "to make a greenway is to make a community" [3]. The socioeconomic influences of greenway include many aspects, such as employment, commercial activity, resident expenditures, real property values, tourism development, community support and partnership, business relocation, and health benefits $[3,5,6]$.

Perhaps the greatest economic contribution of greenways is for tourism, especially in rural areas. Greenway users in urban settings feel comfortable or safe in rural areas [7]. Trails valued by tourists generally tend to be in rural areas, and the economic cost of tourists in rural areas is significantly high $[3,8]$. Greenways generally have a far lower cost per use than sports facilities. Within this context, greenways are of importance to the residents and tourists in rural areas [9]. Many cases have proven that greenway tourism can bring rich economic returns to local communities. Deenihan et al. analyzed the usage of a pilot greenway (cycle way, $42 \mathrm{~km}$ ) in a rural environment in Ireland. In terms of increased tourist expenditure in the area, the facility brings approximately one million euros from tourists annually, providing the facility a payback period of six years [10]. Although farmers and non-farmers agree on the necessity to keep greenways as part of their cultural landscape, the attitude of rural residents toward the development of greenway tourism is different [11]. In Swedish agricultural areas, farmers with a negative attitude usually have unfortunate experiences of people damaging their crops. They also worry about safety. However, some farmers are positive. They like the idea of people coming to the farm to experience farming at close range, watching farmers accomplish their jobs, and becoming inclined to purchase local products. Some farmers have mixed feelings about providing access to their land and ask what is in store for them. This "middle" category seemed skeptical but not hostile [12].

The Food and Agriculture Organization of the United Nations launched a global partnership initiative for the conservation and adaptive management of Globally Important Agricultural Heritage Systems (GIAHS) in 2002. The GIAHS initiative promotes mutual support and synergy between agriculture and tourism through the involvement of public and private sectors in sustainable tourism [13]. From this initiative, developing tourism in agricultural heritage sites (AHS) has always been a concern for scholars. Studies have shown that tourism is an important means for the dynamic conservation of agricultural heritage. Agricultural heritages are a unique tourism resource with great economic potential. Sustainable tourism can in turn effectively protect the local heritage with appropriate development [14-16]. Eco- and agro-tourism have been proven to be viable means of maintaining biological diversity, supporting local communities and cultural heritage, and improving income and well-being [17-20]. However, tourism has two sides. Farmers in many rural areas have considered the tourism industry as an alternative industry, and thus, they got rid of agricultural production and took on the tourism industry [21]. Therefore, the characteristics of agricultural heritage systems must be fully considered and appropriate development modes must be chosen after tourism capacities and potentials are scientifically evaluated for the development of rural tourism $[15,19,20]$. Agricultural heritage plays a key role, but its tourism attraction is always limited; thus, the utilization of other types 
of tourism resources is essential for the sake of the tourism development in AHS [22,23]. Tourism development cannot be separated from community support. Both community attachment and economic dependence have significant effects on positive tourism impact and, in turn, can affect the support for tourism development [24]. Sun et al. applied the community approach to interpret the relationship between agricultural heritage conservation and sustainable tourism development, and proposed that six elements (community, identity, livelihoods, tourism development, farming system, biodiversity and cultural patterns) are interconnected, thereby supporting sustainable development in AHS [25].

\subsection{Research Aim}

Greenway tourism is an increasingly popular eco-tourism product in rural areas. The socioeconomic influence of greenway tourism on AHS is worthy of further discussion. In this study, the authors developed an integrated conceptual model to interpret the correlation between the greenway implementation and agricultural heritage conservation in AHS. The present study took a village on a rural greenway segment (Liantang Spring segment of Zeng River Greenway System) as the case study, and was designed to validate the effectiveness of the conceptual model. The economic, social, cultural factors are likely to affect residents' perceptions of tourism and their willingness to participate in an exchange (support for or opposition to tourism development) [26]. The key goals of the study are as follows: (1) to verify the economic driving role of greenway implementation, (2) to explore the influence of greenway tourism on the social transition, (3) to examine the promotion of greenway tourism for agricultural heritage conservation, (4) to identify the elements which permit the success of the greenway tourism, and (5) to identify strategies and policies for greenway sustainable use and heritage conservation in AHS.

\section{Study Area}

\subsection{Zengcheng District and its Lychee and Black Olive Cultures}

Zengcheng District in Guangzhou City is located in the central part of Guangdong Province, northeast of the Pearl River Delta. Simultaneously, Zengcheng is known to the world for its lychee and black olive, which originated in southern China. According to historical records, Zengcheng already had more than 100 varieties of lychee in the early 11th century. In addition, the Kua Lu lychee, born in 1669, has always been praised as the best lychee variety by Chinese officials and scholars [27]. According to statistics from the Zengcheng Agricultural Bureau in July 2017, a total of 1474 large old trees have been around for over 300 years in Zengcheng. In addition, Zengcheng has been the most important black olive planting region in China since ancient times. According to Huaxiu Guo's paper in 1918, Black Olive Industry in Zengcheng, the annual production of black olive was more than 7.5 million kilograms in the 1910s. At present, the planting area of black olive remains at 1867 hectares, and most trees are over 100 years old. The black olive nutlet carving art of Zengcheng has a history of more than 300 years, and it was selected in the second batch of the China Intangible Cultural Heritage list in 2008 [28].

\subsection{Liantang Village}

Zengcheng Greenway, the earliest recreational greenway system, has become a national model of greenway implementation in China. As an important greenway segment, Liantang Spring is in the north of the central district of Zengcheng and is $5 \mathrm{~km}$ away from Zengcheng, and about $70 \mathrm{~km}$ from Guangzhou. Liantang Spring is an enclosed area surrounded by the Zeng River and Zengcheng-Paitan Road with a total area of $4.38 \mathrm{~km}^{2}$. The greenways can be divided into two categories, namely, the regional (from Zengcheng to Xiaolou, $8 \mathrm{~km}$ ) and local greenway $(6 \mathrm{~km})$. Liantang Spring occupies the territory of two villages, namely, Liantang and Wenshanxia, and the former consists of two parts, Shangliantang and Xialiantang (Figure 1). According to 2016 
statistics, Liantang Village has 180 households, totaling 938 people. Liantang Village was chosen as the case for this study because of the following two aspects:

(1) Liantang Village has long been the planting region for black olive and lychee, which are famous agricultural products of southern China. At present, more than 1800 large old trees $(80 \%$ of them are black olive trees) have been around for over 100 years, and Liantang is home to the largest old tree cluster in Guangzhou. These valuable points of agricultural heritage have become the most important tourism resources in Liantang Spring.

(2) Liantang Spring is a segment of the Zeng River greenway system which is the earliest recreational rural greenway in China. Since the greenway was implemented in September 2008, Liantang Spring has been rapidly developed into a famous rural tourist destination (Figure 2). Liantang Village is the core area of Liantang Spring and is the tourist service center where most tourism resources and reception facilities are mainly distributed [29]. Thus, villagers often express, "no greenway, no Liantang Spring" to emphasize the role of greenway in Liantang. Statistics show that Liantang received 0.5 million tourists in 2016.

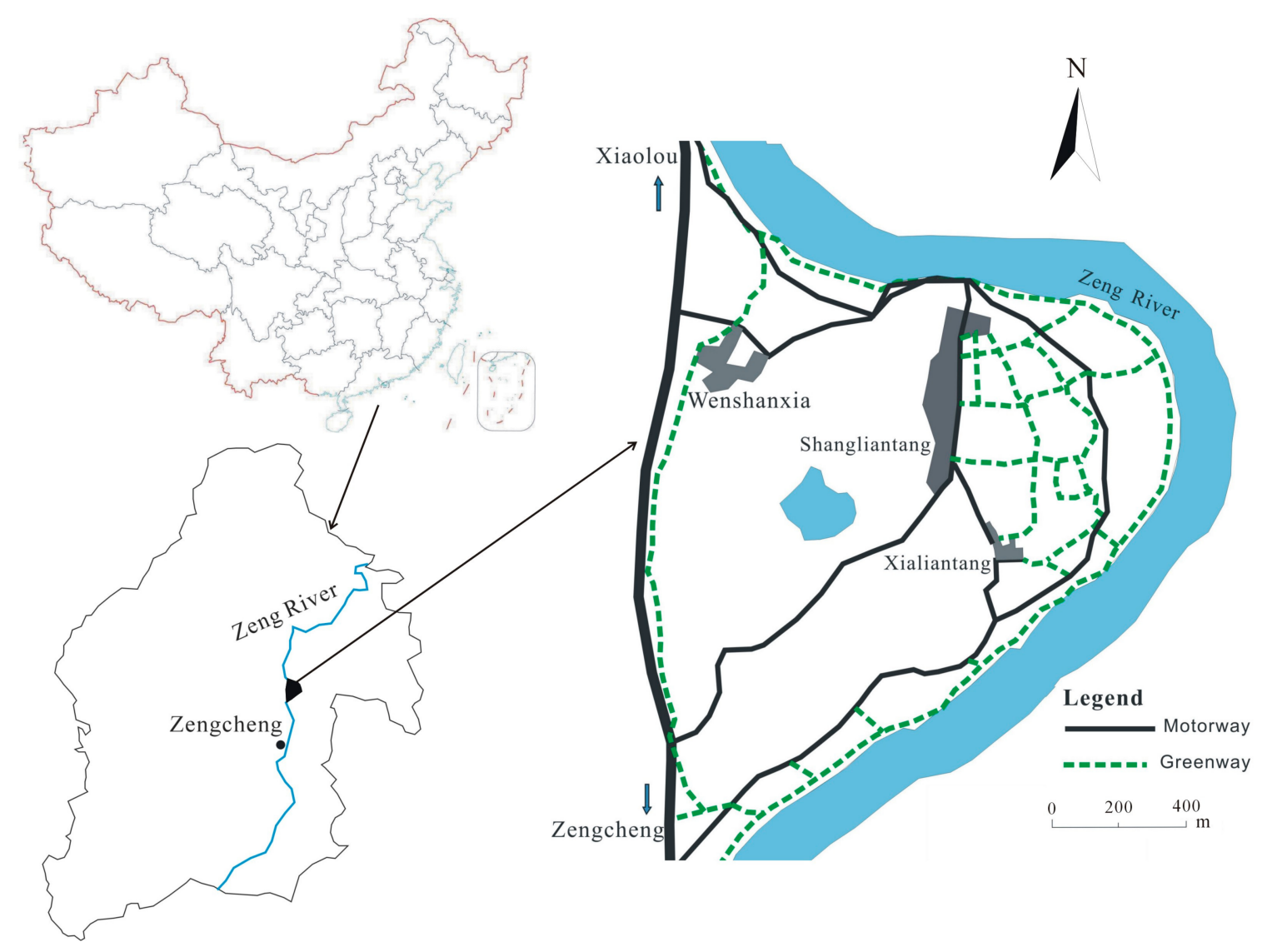

Figure 1. Liantang Spring segment of the Zeng River Greenway System. 


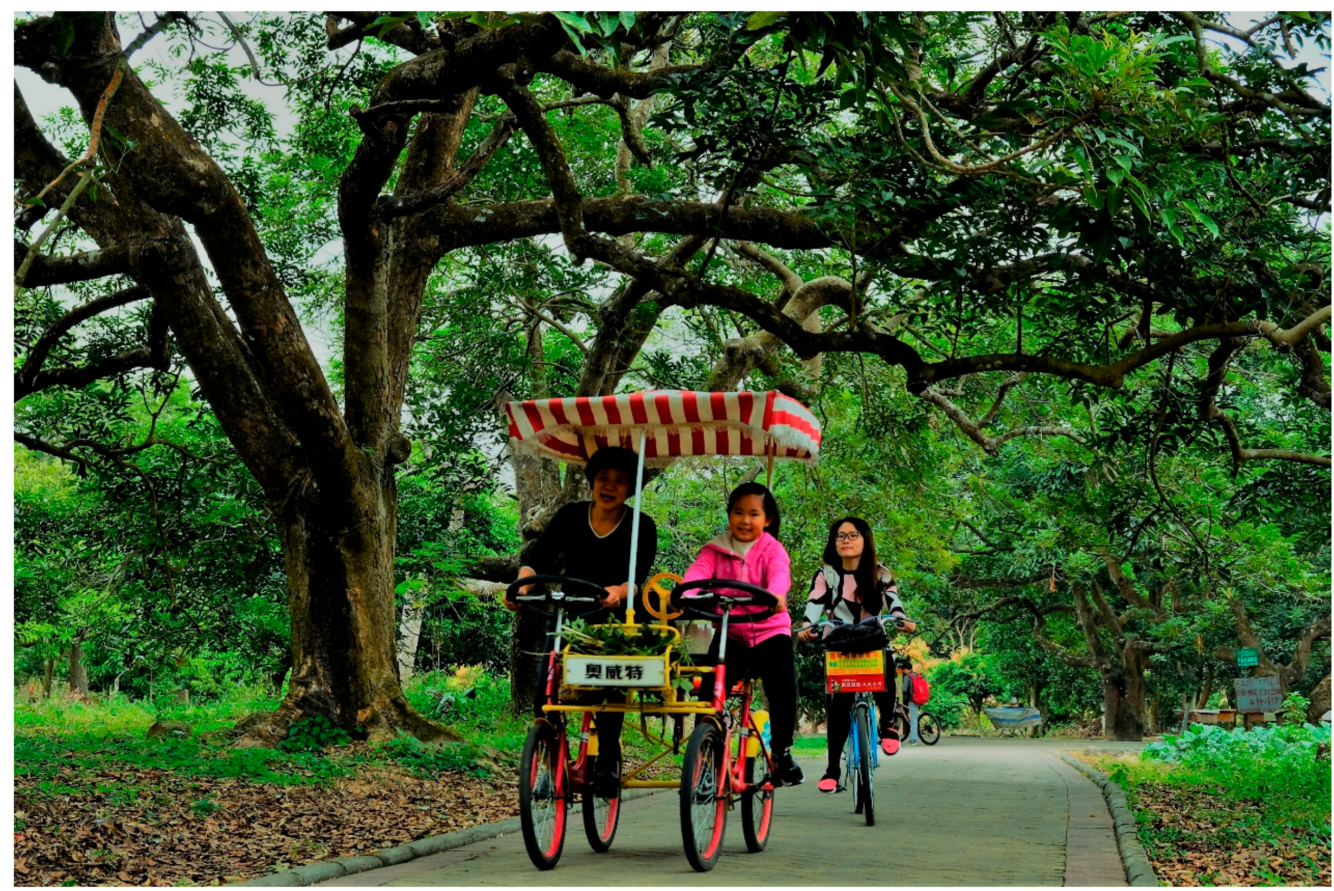

Figure 2. Trail covered by old trees in Liantang (Credit: Rui Nie).

\section{Material and Methods}

Based on previous studies, the authors developed a conceptual model that links the community with agricultural heritage conservation and greenway implementation in an integrated manner (Figure 3). The hypothesis is that the local community is at the core of resource conservation and greenway tourism development processes in AHS as the farming system and traditional agricultural heritage landscape can only be sustained through daily community involvement. If so, then eco-tourism driven by a greenway will make the agricultural heritage more known than before and promote the development of the local economy. Sustainable tourism development will enhance the identity of the community, boosted by lots of positive tourism experiences, and then the agricultural heritage conservation will be strengthened $[25,26]$. The present study is designed to validate the effectiveness of the conceptual model.

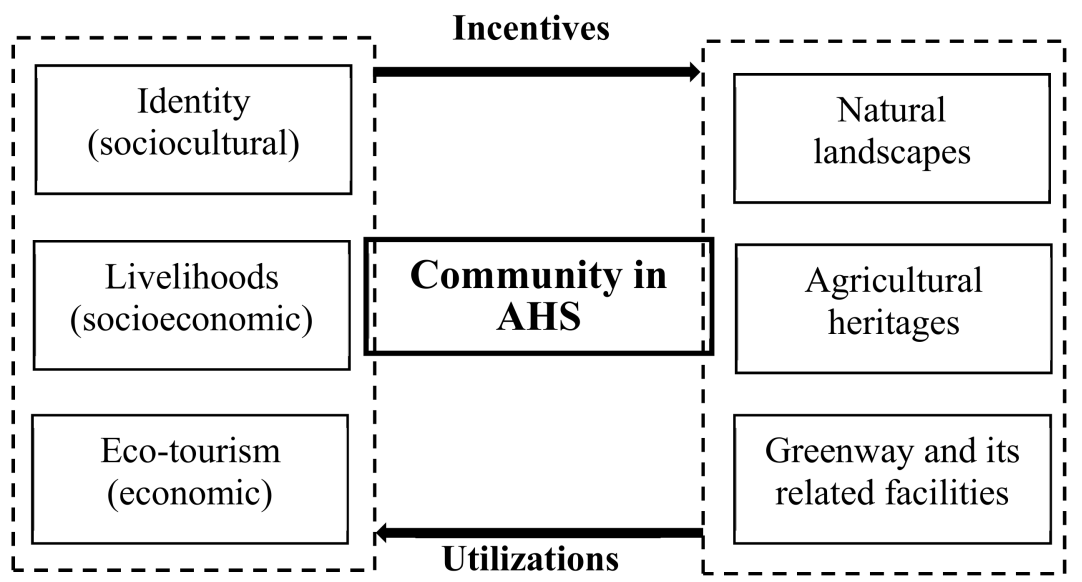

Figure 3. Conceptual model linking the community with agricultural heritage conservation and greenway implementation. 
Participant observations, in-depth interviews, and questionnaires were used to collect relevant data to accomplish the purpose of this study. The authors conducted a long-term follow-up survey to fully understand the search subject. Three on-site surveys were conducted in Liantang in April 2014, November 2016, and June 2017. Field observation and intercept interviews were completed during the periods mentioned above. The authors held interviews to obtain information on greenway implementation and agricultural heritages in Liantang. A total of 35 individuals were interviewed. Among them, two officials of Zengcheng Agricultural Bureau (the responsible unit of Liantang Spring greenway implementation in 2008), one staff member of the Service Center of Liantang Spring, the director of Liantang Village, the president of Liantang Agritainment Association (the boss of Weiwei Agritainment), and the executive of Yuefeng Agricultural Park were strategically selected due to the importance of their role and their involvement at different stages of implementation. The remaining 29 interviewees were randomly selected local residents. All interviews were conducted in a semi-structured manner. The main contents of the interview included the greenway implementation history, agricultural production, old trees management and protection, and touristrelated businesses. The interview results are analyzed in narrative form.

AHS sustainability and the support of residents to tourism development are contingent upon their perceptions of the influences of tourism on their communities $[13,30]$. In this study, the questionnaire for villagers was completed in November 2016. A total of 144 questionnaires were obtained, and 140 of them were complete, resulting in an effectiveness rate of $97 \%$. The survey questionnaire included the following four aspects: namely, personal information of villagers, economic and social influence, as well as the influence of greenway tourism on agricultural heritage conservation. In the second, third, and fourth parts, we mainly used quantitative methods to measure the content of respondents for each question. Regarding the alternative answers for questions of three parts, we used the Likert scale with five points, "highly disagree", "disagree", "uncertain", "agree", and "highly agree", quantified as 1, 2, 3, 4, and 5, respectively. Random sampling was used to distribute the questionnaires to select villagers as survey objects. This study used SPSS 19.0 for the statistical analysis of data.

For sustainable tourism development to be successful, stakeholders must be involved in the process [31]. Previous studies have explored perceptions of residents toward tourism development in relation to its perceived positive and negative effects. Positive effects of tourism encourage the community to support tourism development and to participate in tourism activities, whereas negative effects discourage residents from supporting tourism development [30,32]. Therefore, community attitudes toward tourism must be estimated, and one key criterion is "how is tourism represented by different social groups within local community?" [13] Considering the approval differences of residents, the authors divided the respondents into three types according to their income sources: namely, "Bystander" (33, 23.6\%), "Stakeholder" (59, 42.1\%), and “Undetermined" (48, 34.3\%). This division verified whether differences exist in the perceptions of greenway tourism influences among different population groups. The Bystanders have little or no benefit from greenway tourism, and their main income source is agricultural planting or migrant work. By contrast, the Stakeholders actively participate in tourism development through agritainment management, sales of agricultural product or article for daily use. The Undetermined group seems to have diverse income sources. Some of them work in Zengcheng city area or other nearby cities and live on wages, but they maybe come back to help their family business during holidays and vacations.

\section{Results}

\subsection{Economic Influence}

Liantang was a poor village with unsurfaced roads before the greenway implementation. In 2008, with government financial support of $¥ 1,000,000$, the greenway and its related facilities were built in Liantang. Afterward, the Zengcheng government encouraged villagers to use their own houses to start 
an agritainment which is a farmhouse-based entertainment providing bike rental, food, and residential services for tourists, and the government supported them by the standard of $¥ 30,000$ per household (Figure 4). As a result, 13 agritainments were established in 2009, and the tourism industry rapidly developed within a short period, significantly improving the economy in Liantang. A comparison of the statistics of 2008 and 2016 provided by the Liantang Committee shows that the average annual income of villagers increased from $¥ 4500$ to $¥ 17,000$, and the collective income of Liantang increased from $¥ 40,000$ to $¥ 500,000$. In 2016 , the dividends received by villagers amounted to $¥ 300,000$.

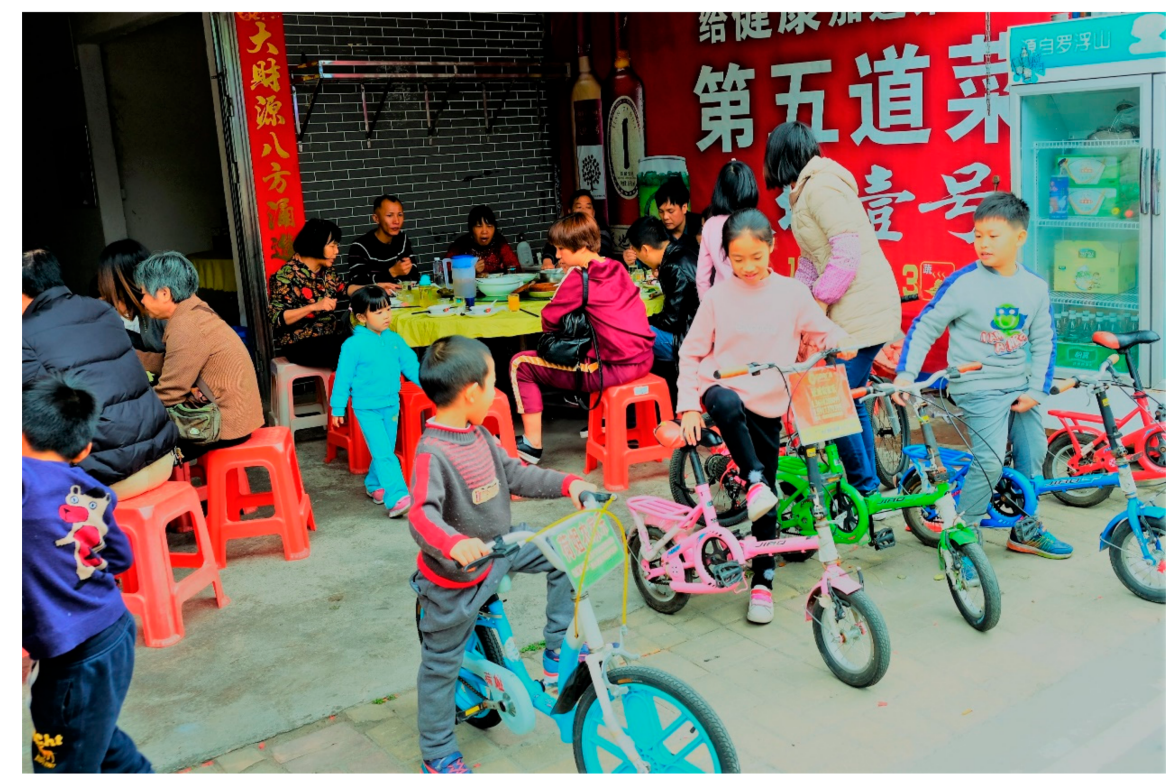

Figure 4. Agritainment provides bike rental and food service for tourists (Credit: Rui Nie).

Starting an agritainment business is the primary means of participating in tourism, especially for the villagers who live along both sides of the street in Liantang. Compared with Xialiantang, Shangliantang has a larger space and better traffic location and condition, which leads to a dominant position in tourism industry for Shangliantang (Table 1). Liantang Village set up the Agritainment Association in 2013 to standardize the development of agritainments. The association initially had 45 members, which decreased to 35 in 2017, mainly because of the fierce market competition. If a tourist dines at an agritainment place, then he can use a bike without a time limit, and the agritainment will be responsible for towing and changing the bike if it is broken down. As a result, it is easy to make a choice to patronize agritainments for tourists who arrive here for the greenway use by car or bus. The director of Liantang said that the annual income of some agritainments can exceed $¥ 1,000,000$ and that even a woman who runs a tofu curd stall earns $¥ 4000$ a day in the peak season. Some villagers living far away from the street are usually employed by the greenway management company. For example, some old women became cleaners with a monthly income of about $¥ 2000$. The floating population in the Liantang also increased dramatically, and they mainly came from Conghua, and Panyu District of Guangzhou City, as well as Dongguan City, and Shaoguan City. Some outsiders rented farmhouses to start an agritainment, and the rest were employed by agritainments. 
Table 1. Statistics on permanent business sites in Liantang.

\begin{tabular}{cll}
\hline Types of Business Sites & \multicolumn{1}{c}{$\begin{array}{c}\text { Number and Location } \\
\text { of Business Sites }\end{array}$} & \multicolumn{1}{c}{ Remark } \\
\hline Agritainment & $\begin{array}{l}\text { 22 agritainments in Shangliantang; } \\
8 \text { in Xialiantang. }\end{array}$ & $\begin{array}{l}\text { All sites provide catering and bike rental } \\
\text { services; 14 sites provide accommodation and } \\
\text { join a chain hotel, namely, Wanjia Cottage }\end{array}$ \\
\hline Store & $\begin{array}{l}\text { 6 stores in Shangliantang, one is } \\
\text { fishing tackle shop; one in Xialiantang }\end{array}$ & $\begin{array}{l}\text { The goods on sale are articles for daily use. } \\
\text { The fishing tackle shop provides convenience } \\
\text { for tourists to go fishing in Zeng River }\end{array}$ \\
\hline $\begin{array}{c}\text { Sales point } \\
\text { of agricultural products }\end{array}$ & $\begin{array}{l}\text { 2 shops and 10 temporary building } \\
\text { points in Shangliantang; 2 temporary } \\
\text { building points in Xialiantang }\end{array}$ & $\begin{array}{l}\text { The goods sold vary with the season, mainly } \\
\text { include salted products of black olive, dried } \\
\text { lychee and longan, tofu curd, peanut oil, } \\
\text { sweet potato, dried fish, and vegetables }\end{array}$ \\
\hline Others & $\begin{array}{l}\text { 2 financial service stations, 1 electric } \\
\text { sightseeing motorcycle club in } \\
\text { Shangliantang; 1 agricultural park }\end{array}$ & $\begin{array}{l}\text { In 2014, Liantang rented a 10.7 ha farmland to } \\
\text { Yuefeng Company as an agricultural park for } \\
\text { growing grapes and pitaya }\end{array}$ \\
\hline & Note: The time of investigation is November 2016.
\end{tabular}

Note: The time of investigation is November 2016.

Respondents were asked to assess the economic influence of tourism in Liantang. Table 2 shows the distribution of "agree" responses of informants in each case. Most respondents acknowledged that the greenway plays a key role in tourism development $(M=4.29)$, and tourism has brought benefits in terms of public services $(M=4.04)$, economic income $(M=3.82)$, and job quantity $(M=3.74)$. According to the comparison of different types of respondents, the Stakeholder group has a stronger perception on the positive economic influence of greenway tourism. By contrast, the Bystander group has the lowest perception level on the same issue. Regarding the negative effect, 35.4\% of Bystanders, about half of the other two types, agreed that tourism has led to price inflation in Liantang.

Table 2. Perception of respondents on the economic influence of greenway tourism.

\begin{tabular}{clccccc}
\hline \multirow{2}{*}{ Number } & \multicolumn{1}{c}{ Variable } & Mean & S.D. & \multicolumn{3}{c}{ Approval Rate (\%) } \\
\cline { 5 - 6 } A1 & & Bystander & Stakeholder & Undetermined \\
\hline & $\begin{array}{l}\text { Greenway has led to } \\
\text { the rapid development } \\
\text { of tourism. }\end{array}$ & 4.29 & 0.773 & 84.9 & 93.3 & 89.6 \\
\hline A2 & $\begin{array}{l}\text { Tourism has brought } \\
\text { more and better public } \\
\text { services than before. }\end{array}$ & 4.04 & 0.925 & 78.8 & 81.4 & 79.2 \\
\hline A3 & $\begin{array}{l}\text { My income has increased } \\
\text { significantly. }\end{array}$ & 3.82 & 0.947 & 54.6 & 86.4 & 70.9 \\
\hline A4 & $\begin{array}{l}\text { Tourism has created job } \\
\text { opportunities, especially } \\
\text { for women. }\end{array}$ & 3.74 & 0.977 & 54.5 & 83.0 & 60.5 \\
\hline A5 & $\begin{array}{l}\text { The number of migrant } \\
\text { workers has decreased. }\end{array}$ & 3.57 & 0.915 & 57.6 & 67.8 & 60.4 \\
\hline A6 & $\begin{array}{l}\text { Tourism has led to } \\
\text { price inflation. }\end{array}$ & 3.16 & 1.123 & 35.4 & 62.7 & 70.8 \\
\hline
\end{tabular}

\subsection{Social Influence}

The development of greenway tourism positively influenced many aspects of Liantang. First, tourism development brought about many improvements for the living environment of the villagers. In recent years, the infrastructures in Liantang, such as paved roads, fitness facilities, household waste sorting and reclaiming points, bus stations, parking lots, public security points, and medical points steadily increased. The quality of life of the villagers has improved largely since 2009. Second, the tourism development has changed the lifestyle of most villagers. Most villagers living along the streets used their farmhouses to start businesses. Some villagers in back streets chose 
to set up stalls to sell agricultural products. In the meantime, some villagers rented their farmhouses to outsiders and moved to Zengcheng. Interestingly, a few still come back for business during the busy season of tourism. Lastly, villagers increasingly lost their lands and disengaged from agriculture. As the villagers realized that planting rice costs too much labor, some paddy fields were converted for fruit planting. In 2014, Liantang expedited the collection of villagers' farmlands, and more than 10 hectares of land were rented for an agricultural park. Inevitably, greenway tourism has brought about negative effects. Some villagers who live in back streets hold that the arrival of tourists and their cars made Liantang noisy and dangerous. They often encountered travel difficulties during the weekend, and their children were no longer free to move. During the harvest seasons of the lychee and black olive (June, July, and October every year), fruits were occasionally plucked by tourists without the permission of landowner. The Liantang Committee always hung sign boards saying "Plucking Banned" on the trunk of old trees, whereas some villagers also hung pesticide bottles to warn tourists (Figure 5). In addition, conflicts emerged between outsiders and natives. Thus, Article Nine of The Regulation of Liantang constituted by the Liantang Committee in 2017, indicated that natives should properly handle relationships with outsiders and create a harmonious environment for the tourism development in Liantang.

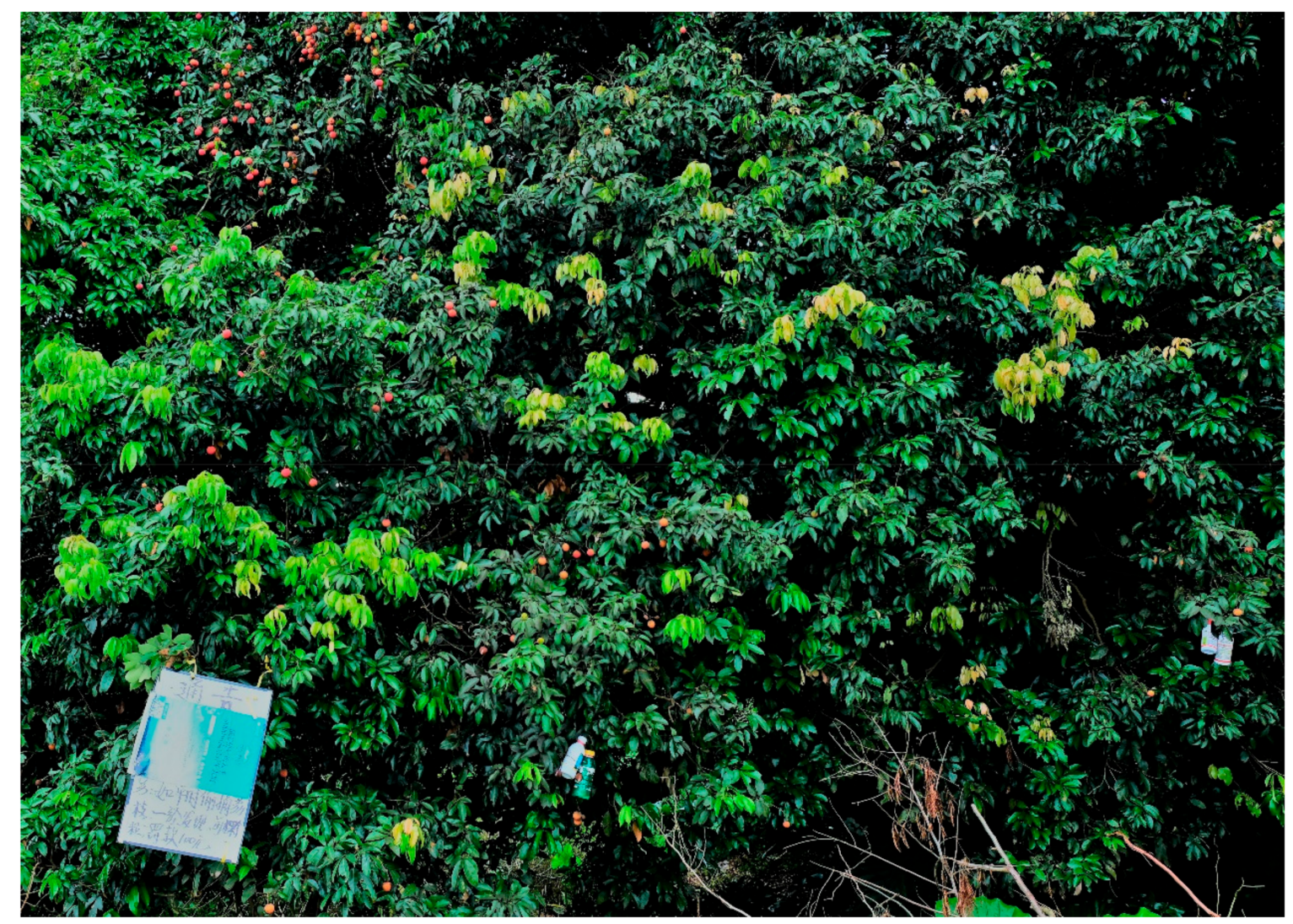

Figure 5. Sign boards and pesticide bottles are hung on a lychee tree during picking season (Credit: Rui Nie).

Respondents were asked to assess the social influence of tourism in Liantang. Table 3 shows the "agree" distribution of informants in each case. The results reveal that the Bystander and Undetermined groups, who are mainly natives compared with the Stakeholder, show more recognition of positive changes in social and cultural aspects, such as Variable B1-B3. However, the Stakeholder group has a higher approval rate on variables B4-B6 which have a close relation with tourism 
industry, and the Bystander group has a higher approval rate on the negative effect of tourism, such as variables B8-B9.

Table 3. Perception of respondents on the social influence of greenway tourism.

\begin{tabular}{|c|c|c|c|c|c|c|}
\hline \multirow{2}{*}{ Number } & \multirow{2}{*}{ Variable } & \multirow{2}{*}{ Mean } & \multirow{2}{*}{ S.D. } & \multicolumn{3}{|c|}{ Approval Rate (\%) } \\
\hline & & & & Bystander & Stakeholder & Undetermined \\
\hline B1 & $\begin{array}{l}\text { Tourism has improved my } \\
\text { living conditions. }\end{array}$ & 3.75 & 0.983 & 57.6 & 76.3 & 73.0 \\
\hline B2 & $\begin{array}{l}\text { My personal quality of life } \\
\text { is enhanced. }\end{array}$ & 3.86 & 0.751 & 84.9 & 77.9 & 75.0 \\
\hline B3 & My personal hygiene is improved. & 3.87 & 0.896 & 78.8 & 74.6 & 77.1 \\
\hline B4 & People speak Mandarin. & 3.55 & 0.984 & 60.6 & 66.1 & 62.5 \\
\hline B5 & More outsiders come here to work. & 3.46 & 1.069 & 45.4 & 62.7 & 70.8 \\
\hline B6 & More outsiders come to do business. & 3.73 & 0.936 & 63.7 & 77.9 & 64.6 \\
\hline B7 & $\begin{array}{c}\text { The number of villagers engaged in } \\
\text { agriculture decreased. }\end{array}$ & 3.69 & 0.864 & 66.7 & 76.3 & 70.8 \\
\hline B8 & $\begin{array}{l}\text { My routine of life and work } \\
\text { are disturbed. }\end{array}$ & 3.90 & 0.867 & 87.9 & 66.1 & 77.1 \\
\hline B9 & Security situation deteriorated. & 3.21 & 1.085 & 54.6 & 44.1 & 43.7 \\
\hline
\end{tabular}

\subsection{Effect on the Conservation of Agricultural Heritage}

In the early 18th century, Dajun Qu, a noted writer in Guangdong, stated in his influential book A New Encyclopedia of Guangdong that farmers living in mountain areas of Guangzhou would like to plant some black olive trees for leaving the property to their descendants owing to the high yield and longevity of black olive. It simply answers the question, "Why does Liantang have so many old trees nowadays?" Since the 1980s, most trees have been distributed to villagers to manage. The rest belongs to the village community, and all villagers can submit a tender after the yield evaluation of every tree in a few years. The villager who wins the bidding would be responsible for the management of trees and paying the rental fee. Most fruits are sold abroad, some are paid for by tourists, and the rest are left for the villagers to consume. Raw fruits of the black olive cannot be eaten, thus, villagers always process them as sealed preserves, called Langjiao in Chinese, which are popular among tourists.

Respondents were asked to assess the tourism influence on the protection of old trees in their community. Table 4 shows the "agree" distribution of informants in each case. The majority of respondents reported that the landscape of old trees is an important element to attract tourists $(\mathrm{M}=4.27)$, that tourists like lychee, black olive, and other local agricultural products in Liantang $(\mathrm{M}=3.89)$, and that the number of tourists increases during the picking season of the lychee and black olive $(\mathrm{M}=4.00)$. The development of tourism effectively improved the economic benefits of these old trees. The director of Liantang said that the annual yield of black olive trees was from $5000 \mathrm{~kg}$ to $50,000 \mathrm{~kg}$, and the price for the purchase, $¥ 16-20$ per kilogram, increased by four to five times in the last eight years. The findings reveal that most villagers clearly understand the heritage value of old trees. The majority of respondents reported that old trees are precious heritages which must be protected carefully $(\mathrm{M}=4.19)$. Most respondents reached a consensus that the protection of old trees is conducive to the development of greenway tourism $(M=4.02)$, that the government should promote the declaration of China-Nationally Important Agricultural Heritage Systems (China-NIAHS) to better protect old trees $(\mathrm{M}=4.04)$, and they should actively support and participate in the protection of old trees $(\mathrm{M}=4.12)$. The Bystander group has the highest approval rate on variables $\mathrm{C} 2$ and $\mathrm{C} 7-\mathrm{C} 9$. The Stakeholder group is clearly more aware of the agricultural heritage value and has the highest approval rate on variables $\mathrm{C} 1, \mathrm{C} 3-\mathrm{C} 6$, and $\mathrm{C} 10-\mathrm{C} 12$. Clearly, the Stakeholder is the most active group to support the declaration of China-NIAHS. 
Table 4. Perception of respondents on the influence of greenway tourism on agricultural heritage conservation.

\begin{tabular}{|c|c|c|c|c|c|c|}
\hline \multirow{2}{*}{ Number } & \multirow{2}{*}{ Variable } & \multirow{2}{*}{ Mean } & \multirow{2}{*}{ S.D. } & \multicolumn{3}{|c|}{ Approval Rate (\%) } \\
\hline & & & & Bystander & Stakeholder & Undetermined \\
\hline $\mathrm{C} 1$ & $\begin{array}{l}\text { Old trees are precious } \\
\text { heritages and must be } \\
\text { protected carefully. }\end{array}$ & 4.19 & 0.745 & 90.9 & 94.9 & 81.3 \\
\hline $\mathrm{C} 2$ & $\begin{array}{l}\text { The landscape of old trees is } \\
\text { an important element to } \\
\text { attract tourists. }\end{array}$ & 3.89 & 0.793 & 81.9 & 77.9 & 75.0 \\
\hline $\mathrm{C} 3$ & $\begin{array}{l}\text { Tourists like the lychee, } \\
\text { black olive, and other local } \\
\text { agricultural products. }\end{array}$ & 4.27 & 0.610 & 90.7 & 98.3 & 91.7 \\
\hline $\mathrm{C} 4$ & $\begin{array}{l}\text { The number of tourists } \\
\text { increase considerably during } \\
\text { the picking season of lychee } \\
\text { and black olive. }\end{array}$ & 4.00 & 0.814 & 78.9 & 86.4 & 83.3 \\
\hline C5 & $\begin{array}{l}\text { Economic benefits of lychee } \\
\text { and black olive have } \\
\text { greatly improved. }\end{array}$ & 3.89 & 0.759 & 75.8 & 84.7 & 70.8 \\
\hline C6 & $\begin{array}{l}\text { I had a clearer cognition for } \\
\text { the value of old trees } \\
\text { than before. }\end{array}$ & 3.86 & 0.819 & 75.8 & 81.3 & 75.0 \\
\hline $\mathrm{C} 7$ & $\begin{array}{l}\text { I have raised awareness } \\
\text { of old trees protection. }\end{array}$ & 3.94 & 0.722 & 84.9 & 81.3 & 68.7 \\
\hline $\mathrm{C} 8$ & $\begin{array}{l}\text { The management of old } \\
\text { trees has been strengthened. }\end{array}$ & 3.94 & 0.712 & 90.9 & 79.6 & 73.0 \\
\hline C9 & $\begin{array}{l}\text { The number of old trees } \\
\text { felled declined. }\end{array}$ & 3.86 & 0.861 & 81.8 & 76.3 & 64.6 \\
\hline $\mathrm{C} 10$ & $\begin{array}{l}\text { The government should } \\
\text { promote the declaration } \\
\text { of China-Nationally } \\
\text { Important Agricultural } \\
\text { Heritage Systems. }\end{array}$ & 4.04 & 0.714 & 66.8 & 86.4 & 75.0 \\
\hline $\mathrm{C} 11$ & $\begin{array}{l}\text { I should actively support } \\
\text { and participate in the } \\
\text { protection of old trees. }\end{array}$ & 4.12 & 0.629 & 78.8 & 93.2 & 85.4 \\
\hline $\mathrm{C} 12$ & $\begin{array}{l}\text { Protection of old trees is } \\
\text { conducive to greenway } \\
\text { tourism development. }\end{array}$ & 4.02 & 0.605 & 78.8 & 89.8 & 85.4 \\
\hline
\end{tabular}

\section{Discussion}

\subsection{The Greenway as an Approach for AHS Sustainability}

Since the 1990s, the rural greenway implementation has increased in popularity worldwide. As a linear open space, a greenway can early connect rural tourism resources. At present, greenways are an acknowledged tool for rural sustainable development because they help to protect and manage environmental heritage, promote economic activities, and enhance the social assets of rural areas $[10,33]$. The authors proposed a conceptual model that links the community with agricultural heritage conservation and greenway implementation. Results of the case study of Liantang indicate that the related elements in the model are interconnected and thus support the agricultural heritage conservation and greenway tourism development in AHS. Greenways are used primarily for recreation but often incorporated varying elements of transportation. The intensity of use always varies widely among individual segments of the same trail, not just among different trails [1]. Liantang greenway users are mainly categorized in three groups: namely, recreation tourist, surrounding resident, and passer-by. The success of this greenway in eco-tourism development is attributed to its ability to attract numerous tourists who visit for recreation from urban areas [29]. Simultaneously, AHS is 
a special kind of rural tourist destinations, and its particularity needs concern. Sun et al. explored the characteristics of tourism resource utilization by analyzing three types of GIAHS and found that the tourism value of agricultural landscape heritage is the highest of the three [16]. As an agricultural landscape heritage site, apart from more than 1800 large old trees, Liantang still has rich natural and cultural tourism resources, such as the Zeng River, pastoral scene, agricultural park and local delicacies. Therefore, the greenway implementation can promotes rapid development of tourism effectively.

Measuring the success of greenway implementation in AHS, we hold that some factors should be noted: (1) AHS should have a large number of circular trails (a local greenway system) which can make tourists to stay there for a long time, not simply to pass by; (2) it is better for greenway sustainable use if the related agricultural heritage possesses high tourism values, and other types of tourism resources can be combined together in the area; (3) the government, as a driven factor, should play an important role in supporting greenway implementation and tourism development; (4) AHS community support and participation, also a basic element, is essential for the success of the greenway; (5) in the perspective of tourism, a successful rural greenway is mainly used by citizens of nearby cities instead of local residents, thus, the AHS distance to cities is also a key influence factor probably; (6) convenient transportation and facilities are always significant for greenway users, obviously for the tourists from afar. In general, the success of Liantang greenway can be copied as long as the key rules mentioned above are followed in AHS of other regions and countries. However, the tourism influences may vary among rural communities in AHS. We cannot easily generalize either positive or negative experiences from one place to another; thus, the conclusion of this study may not have universal applicability. However, this study presents a successful example of the dynamic conservation of agricultural heritage in AHS, and reveals that the multi-dimensional values of agricultural heritage can be achieved, and a mutually beneficial relationship will then be formed between the tourism and agricultural heritage conservation as soon as the correct eco-tourism is developed.

In this study, the authors only assessed the economic and sociocultural influences of greenway implementation. Actually, ecological protection is an important function of greenways as it can protect important habitats from land development and provide corridors for people and wildlife. However, greenways may also have a number of negative effects on wildlife [34]. Biodiversity is the most important monitoring index in AHS. Therefore, the ecological effect of greenway implementation should be studied more. In addition, evaluating indicators of AHS tourism influences could be refined, and some quantitative research methods (such as cultural ecosystem services approach and holistic approach) can be further explored [35-37].

\subsection{Strategies for Greenway Sustainable Use and Heritage Conservation}

Agricultural landscapes in AHS tourism are more sensitive than the agricultural facilities used in rural tourism. This study proposes to ensure the sustainable use of rural greenway without any harm to agricultural heritages and to realize a dynamic conservation of AHS, and presents a series of suggestions as follows:

For the local government. In rural areas, as most narrow motorways are used by greenway users, those roadways should be widened and reconstructed to facilitate the separation of pedestrian, cyclist, and vehicular circulation. In this manner, the greenway users can safely enter the AHS. The phenomena of abnormal death and disorderly deforestation still occur because of the low-level regulations on the protection of old trees and the absence of corresponding implementation rules (Figure 6). The forestry authorities under the government should establish a long-term management mechanism of old tree protection and accomplish the goal that "every tree is managed well, and every tree has a file" in AHS. Moreover, a trail-user ordinance should be promulgated soon to reduce the negative behavior of tourists in AHS (Figure 7). The government should attach great importance to the declaration of China-NIAHS and GIAHS. The cultural and tourism brand will be more influential if the declaration is successful, and it will help the greenway sustainable use in turn in AHS. The government plays an important role in integration and balancing the benefit of local 
people and external investors. Any future action for tourism development should prioritize local communities in terms of access to livelihood means while developing tourism facilities [13].

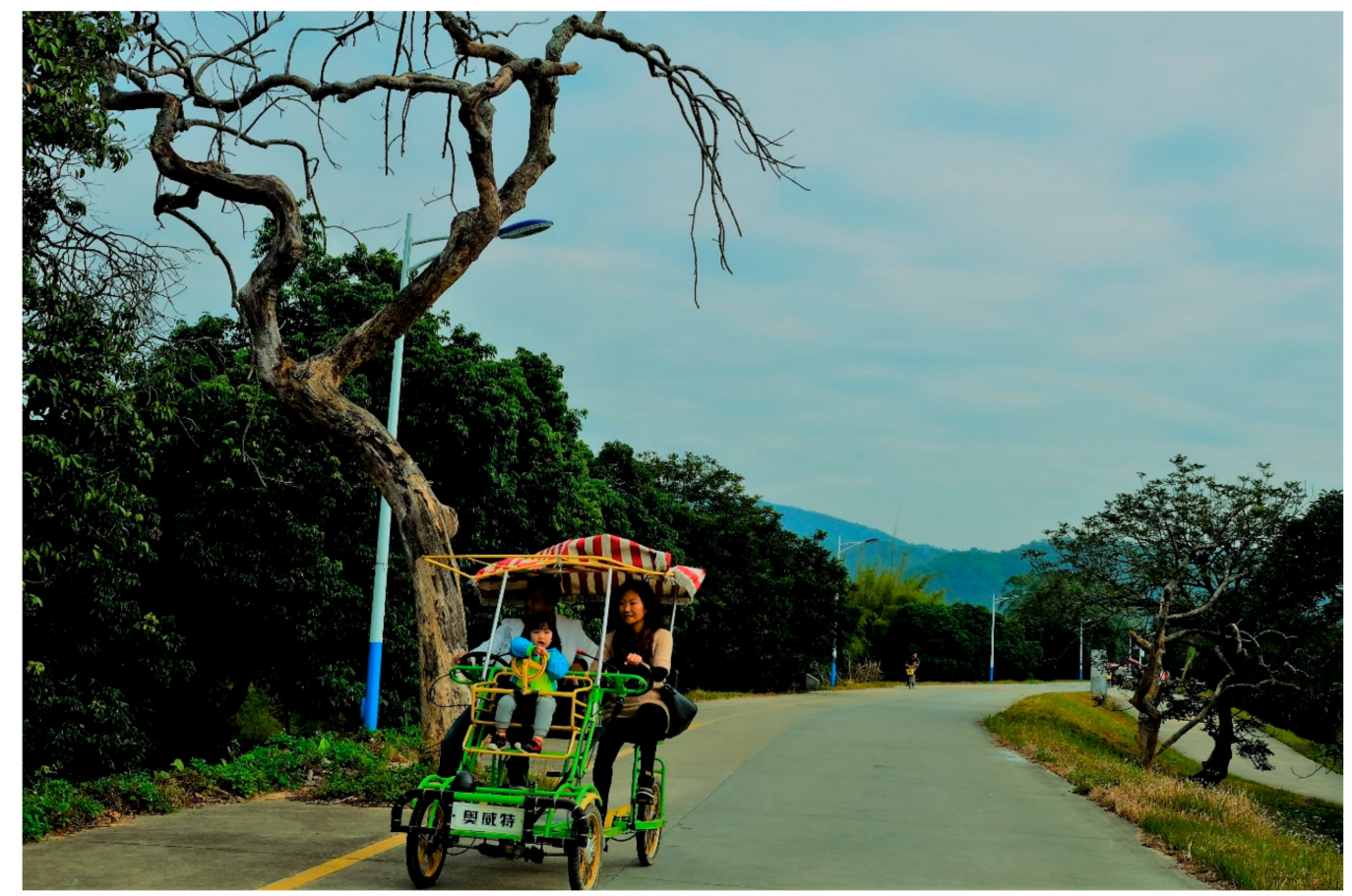

Figure 6. Two old trees die on the river bank because of road construction (Credit: Rui Nie).

For the community. The community participation and the bottom-up management approach are considered to be important for sustainable tourism and heritage conservation [25]. Public facilities play an important role in the tourism service functions of rural greenways. The provision of all kinds of community services and facilities (such as parking lot, drinking water equipment, public toilet, pavilion, seat, and other facilities) is usually limited because of the lack of scientific assessment on tourism development at the beginning of greenway planning. Therefore, carrying out a "second planning" and strengthening the construction of supporting facilities are necessary to provide safe and comfortable conditions for greenway users. The construction planning and management of villages should be improved further. Many existing problems, such as illegal land use, unordered and blindly building, illegal street stall business, and abandoned farmlands, must be resolved as soon as possible. Villagers are the first line of defense in protecting old trees and participating in tourism. The community should run regular training courses to acquaint villagers with matters regarding the protection of old trees. Lastly, the Agritainment Association should make further efforts to regularize the business behavior of its member units. 


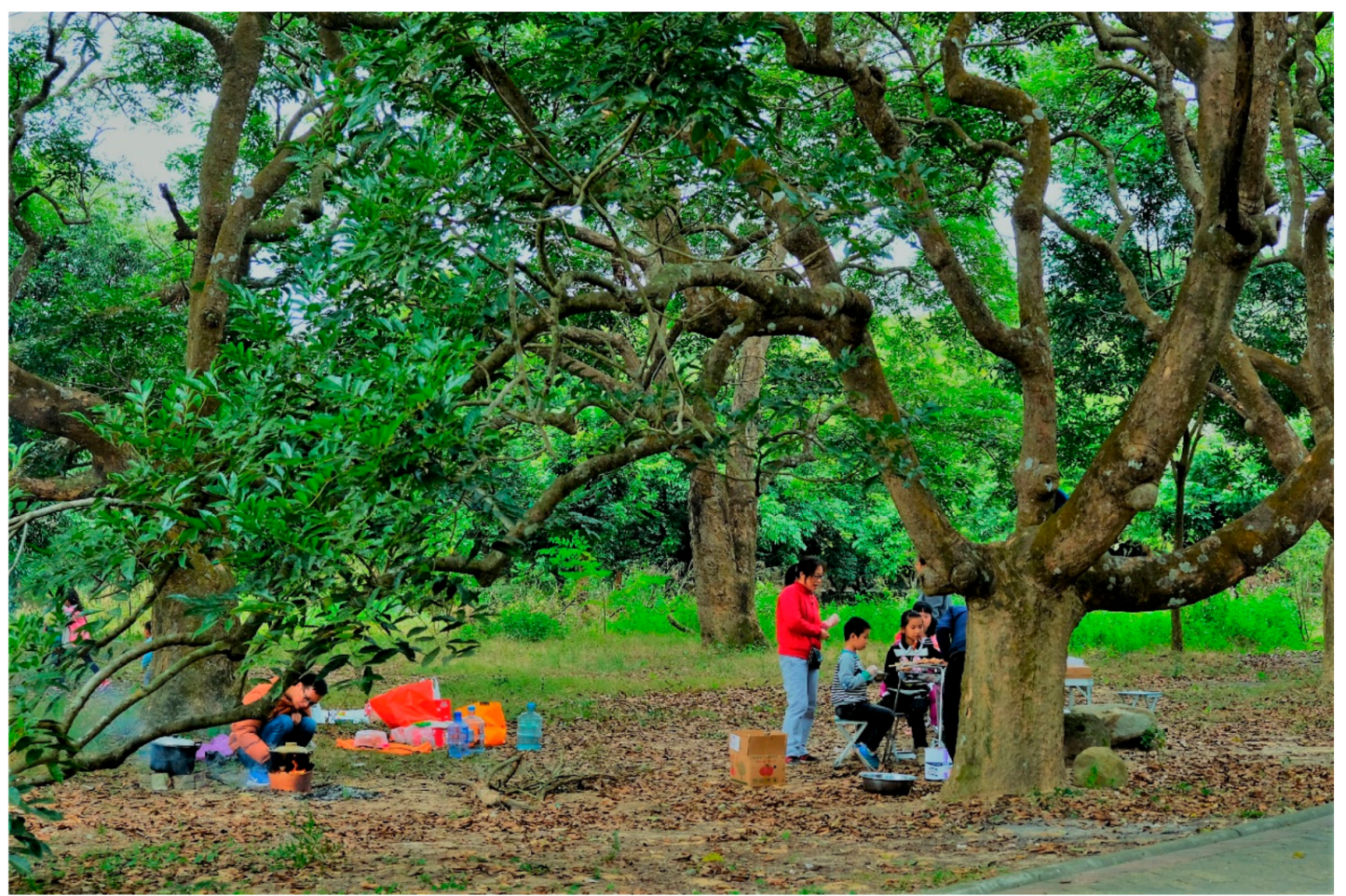

Figure 7. Tourists use fire to cook in the woods (Credit: Rui Nie).

\section{Conclusions}

The concept of "dynamic conservation" is rooted in the idea that opportunities for agricultural heritage conservation are mostly found in the daily lives of rural populations, responding to their needs and expectations [17]. In China, along with the rapid urbanization and transformation of farmers' modes of production and lifestyles, agricultural heritage dynamic conservation and adaptive management have become focal and difficult problems in academic circles. This study provides a new case of dynamic conservation in AHS, especially for agricultural landscape heritage sites. The following conclusions are drawn: (1) Greenway implementation successfully promoted the emergence and rapid development of tourism which significantly improved the economy of the heritage area and effectively raised the income of the villagers in AHS. Liantang, the case of this study, was transformed from an originally poor into a well-off village. Sources of the villagers' income mainly include agritainment business, agricultural product sales, tourist-related business wages, land leases, and house rentals. (2) Tourism development brought profound changes to the rural society in AHS. Most villagers greatly enhanced their quality of life because of the continuous infrastructure improvement. Local employment opportunities increased, particularly for women in service industries. However, the normal life and production order of villagers were disturbed to some extent. (3) Tourism and agricultural heritage conservation formed a mutually beneficial relationship. Villagers had a sober cognition of the value of old trees, and their heritage conservation consciousness was enhanced, providing a folk basis for the government to further protect agricultural heritage. (4) The difference in the source of economic income affected the judgment of residents on the tourism influence to some extent. Three groups of respondents have cognitive differences in the influence of tourism. Greenway sustainable use must be supported by more residents, and thus, greenway managers should pay sufficient attention to the contrasting degrees of residents' recognition in AHS. In conclusion, this study not only provides a successful example of rural greenway tourism but also indicates that a mutually beneficial relationship will then be formed between the tourism development and agricultural heritage conservation as soon as the correct eco-tourism is developed in AHS. 
Acknowledgments: This research was financially supported by the China National Social Science Fund Major Project of the National Planning Office of Philosophy and Social Science (16ZDA123). The authors sincerely thank to Miss Yu He, Miss Yunfang Dong, and others for their work on the surveys.

Author Contributions: The authors undertook different tasks for this study. Jia'en Zhang designed the framework and provided direction for the research. Fei Zhao and Rui Nie wrote the manuscript.

Conflicts of Interest: The authors declare no conflict of interest.

\section{References}

1. Lindsey, G. Use of urban greenways: Insights from Indianapolis. Landsc. Urban Plan. 1999, 45, $145-157$. [CrossRef]

2. Fábos, G.J.; Ryan, R.L. An introduction to greenway planning around the world. Landsc. Urban Plan. 2006, 76, 1-6. [CrossRef]

3. Little, C. Greenways for American; Johns Hopkins University Press: Baltimore, MD, USA, 1990.

4. Yu, K.; Li, D.; Li, N. The evolution of greenways in China. Landsc. Urban Plan. 2006, 76, 223-239. [CrossRef]

5. Siderelis, C.; Moore, R. Outdoor recreation net benefits of rail-trails. J. Leisure Res. 1995, 27, $344-359$. [CrossRef]

6. Nicholls, S.; Crompton, J.L. The impact of greenways on property values: Evidence from Austin, Texas. J. Leisure Res. 2005, 37, 321-341. [CrossRef]

7. Pettengill, P.R.; Lee, B.H.Y.; Manning, R.E. Traveler perspectives of greenway quality in northern New England. Transp. Res. Rec. 2012, 2314, 31-40. [CrossRef]

8. Lumsdon, L.; Downward, P.; Cope, A. Monitoring of cycle tourism on long distance trails: The North Sea Cycle Route. J. Transp. Geogr. 2004, 12, 13-22. [CrossRef]

9. Palau, R.; Forgas, S.; Blasco, D.; Ferrer, B. An analysis of greenways from an economic perspective. Tour. Plan. Dev. 2012, 9, 15-24. [CrossRef]

10. Deenihan, G.; Caulfield, B.; O'Dwyer, D. Measuring the success of the Great Western Greenway in Ireland. Tour. Manag. Perspect. 2013, 7, 73-82. [CrossRef]

11. Burel, F.; Baudry, J. Social, aesthetic and ecological aspects of hedgerows in rural landscapes as a framework for greenways. Landsc. Urban Plan. 1995, 33, 327-340. [CrossRef]

12. Peterson, A.; Gyllin, M.; Haaland, C.; Larsson, A. Recreation in Swedish agricultural areas: Public attitudes to multifunctional greenway designs. In Fábos Conference on Landscape and Greenway Planning; Fábos, J.G., Ed.; Corvinus University of Budapest: Budapest, Hungary, 2010; pp. 503-509.

13. Vafadari, K. Review: Planning sustainable tourism for agricultural heritage landscapes. Ritsumeikan J. Asia Pac. Stud. 2013, 32, 75-89.

14. Tian, M.; Min, Q.; Tao, H.; Yuan, Z.; He, L.; Lun, F. Progress and prospects in tourism research on Agricultural Heritage Sites. J. Resour. Ecol. 2014, 5, 381-389.

15. Min, Q.; Sun, Y.; Cheng, S.; Wang, X. Primary study on the features and development of GIAHS's tourism resources. Econ. Geogr. 2007, 27, 856-859. (In Chinese)

16. Sun, Y.; Min, Q.; Liu, M. Tourism resources utilization of different types of agricultural heritage systems. Resour. Sci. 2013, 35, 1526-1534. (In Chinese)

17. Koohafkan, P.; Altieri, M.A. Forgotten Agricultural Heritage: Reconnecting Food Systems and Sustainable Development; Earthscan Food and Agriculture Series; Routeledge: London, UK, 2016.

18. Zhang, Y.; Min, Q.; Li, H.; He, L.; Zhang, C.; Yang, L. A conservation approach of Globally Important Agricultural Heritage Systems (GIAHS): Improving traditional agricultural patterns and promoting scale-production. Sustainability 2017, 9, 295. [CrossRef]

19. Min, Q.; Zhang, Y.; Jiao, W.; Sun, X. Responding to common questions on the conservation of agricultural heritage systems in China. J. Geogr. Sci. 2016, 26, 969-982. [CrossRef]

20. Sun, Y. Research review on agricultural heritage systems and its tourism development. J. Landsc. Res. 2012, $4,54-58$.

21. Busby, G.; Rendle, S. The transition from tourism on farms to farm tourism. Tour. Manag. 2000, 21, 635-642. [CrossRef]

22. Vafadari, K. Exploring tourism potential of Agricultural Heritage Systems: A case study of the Kunisaki Peninsula, Oita Prefecture, Japan. Issues Soc. Sci. 2013, 1, 33-52. [CrossRef] 
23. Zhao, F.; Wu, Z. Research on agricultural heritage tourism planning: A case study of Zengcheng Simiao rice. Agric. Archaeol. 2011, 4, 385-388. (In Chinese)

24. Chen, C.F.; Chen, P.C. Resident attitudes toward heritage tourism development. Tour. Geogr. 2010, 12, 525-545. [CrossRef]

25. Sun, Y.; Wang, J.; Liu, M. Community perspective to agricultural heritage conservation and tourism development. J. Resour. Ecol. 2013, 4, 258-266.

26. Yoon, Y.; Gursoy, D.; Chen, J.S. Validating a tourism development theory with structural equation modeling. Tour. Manag. 2001, 22, 363-372. [CrossRef]

27. Zhao, F. Kua Lu Lychee in Zengcheng District: Its History and Culture; China Agriculture Press: Beijing, China, 2015. (In Chinese)

28. Zhao, F.; Ni, G.; Zhang, J. Research on plantation and utilization of the black olive in historical period of Zengcheng. Agric. Archaeol. 2014, 1, 216-221. (In Chinese)

29. Zhao, F.; Gong, J.; Li, Y. Research on the recreational greenway user's behavior and experience satisfaction in rural areas. Areal Res. Dev. 2016, 35, 110-114. (In Chinese)

30. Rasoolimanesh, S.M.; Ringle, C.M.; Jaafar, M.; Ramayah, T. Urban vs. rural destinations: Residents' perceptions, community participation and support for tourism development. Tour. Manag. 2017, 60, 147-158. [CrossRef]

31. Byrd, E.T. Stakeholders in sustainable tourism development and their roles: Applying stakeholder theory to sustainable tourism development. Tour. Rev. 2007, 62, 6-13. [CrossRef]

32. Sharpley, R. Host perceptions of tourism: A review of the research. Tour. Manag. 2014, 42, 37-49. [CrossRef]

33. Palmisano, G.O.; Govindan, K.; Loisi, R.V.; Sasso, P.D.; Roma, R. Greenways for rural sustainable development. Land Use Policy 2016, 50, 429-440. [CrossRef]

34. Mundet, L.; Coenders, G. Greenways: A sustainable leisure experience concept for both communities and tourists. J. Sustain. Tour. 2010, 18, 657-674. [CrossRef]

35. Wu, C.J.; Isaksson, K.; Antonson, H. The struggle to achieve holistic landscape planning: Lessons from planning the E6 Road Route through Tanum World Heritage Site, Sweden. Land Use Policy 2017, 67, 167-177. [CrossRef]

36. Carvalho-Ribeiro, S.; Pinto Correia, T.; Paracchini, M.L.; Schüpbach, B.; Sange, O.A.; Vanderheyden, V.; Southern, A.; Jones, P.; Contreras, B.; O’Riordan, T. Assessing the ability of rural agrarian areas to provide cultural ecosystem services (CES): A multi scale social indicator framework (MSIF). Land Use Policy 2016, 53, 8-19. [CrossRef]

37. Milcu, A.I.; Hanspach, J.; Abson, D.; Fischer, J. Cultural ecosystem services: A literature review and prospects for future research. Ecol. Soc. 2013, 18, 44. [CrossRef]

(C) 2018 by the authors. Licensee MDPI, Basel, Switzerland. This article is an open access article distributed under the terms and conditions of the Creative Commons Attribution (CC BY) license (http://creativecommons.org/licenses/by/4.0/). 